\title{
Processing quality of potato tubers produced during autumn and spring and stored at different temperatures
}

\author{
Sergio T de Freitas'; Engil Isadora P Pereira'; ${ }^{1}$ Ana Cecília S Gomez²; Auri Brackmann³; Fernando \\ Nicoloso $^{3}$; Dilson A Bisognin ${ }^{3 *}$ \\ ${ }^{1}$ Univ. of California, Depart. of Plant Sciences, One Shields Ave, Davis, CA, 95616 - USA; stfreitas@ucdavis.edu; isapereira@ucdavis. \\ edu; ${ }^{2}$ University of the Republic, Depart. of Vegetable Production, Montevideo, 12900 - Uruguay; acsilver@fagro.edu.uy; ${ }^{3}$ UFSM- \\ Depto. Horticultura, 97105-900 Santa Maria-RS, Brazil; auri@brackmann.com.br; ftnicoloso@yahoo.com; dilsonb@smail.ufsm.br, \\ *corresponding author
}

\begin{abstract}
The objective of this work was to access processing quality of potato clones (Solanum tuberosum) Asterix, SMINIA793101-3, and Missaukee cultivated during spring and autumn growing seasons and stored at $4,8,12$, or $25^{\circ} \mathrm{C}$. Clones grown in spring had shorter dormancy than clones grown in autumn. Potato tubers grown in spring and autumn and stored at $4^{\circ} \mathrm{C}$, as well as tubers grown in autumn and stored at $8^{\circ} \mathrm{C}$ had no sprouting for six months. Among clones grown in autumn, the longest dormancy period during storage at $12^{\circ} \mathrm{C}$ was observed in the clone SMINIA793101-3, and at $25^{\circ} \mathrm{C}$ was in the clone Asterix. In potato tubers grown in spring, the longest dormancy period during storage at $8^{\circ} \mathrm{C}$ was observed in the clones SMINIA793101-3 and Missaukee, at $12^{\circ} \mathrm{C}$ was in the clone SMINIA793101-3, and at $25^{\circ} \mathrm{C}$ was in the clones Asterix and Missaukee. Potato tubers grown in spring had higher dry matter, starch content, and respiration rates, and lower reducing sugar, and total polyphenol content. The only exception was the Missaukee that had similar dry matter content in both growing seasons. In general, storage at $4^{\circ} \mathrm{C}$ and $8^{\circ} \mathrm{C}$ were more effective in reducing respiration rates and maintaining higher dry mater content of potato tubers. Chip darkening, reducing sugars, and total polyphenol content increased during storage of potato tubers. Darker chip color, higher reducing sugars and polyphenol content were obtained during storage at temperatures of $4^{\circ} \mathrm{C}$ and $8^{\circ} \mathrm{C}$. These results suggest that the best storage temperature depends on genotype, tuber physiological age, and growing conditions.
\end{abstract}

Keywords: Solanum tuberosum, dry matter, respiration, chip color, reducing sugars, polyphenols.

\section{RESUMO}

Qualidade de processamento de tubérculos de batata produzidos no outono e na primavera e armazenados em diferentes temperaturas

O objetivo deste trabalho foi determinar a qualidade de processamento dos clones de batata (Solanum tuberosum) Asterix, SMINIA793101-3, e Missaukee cultivados durante outono e primavera e armazenados a $4,8,12$, ou $25^{\circ} \mathrm{C}$. Clones produzidos na primavera tiveram menor período de dormência que clones produzidos no outono. Tubérculos produzidos na primavera e outono e armazenados a $4^{\circ} \mathrm{C}$, assim como tubérculos produzidos no outono e armazenados a $8^{\circ} \mathrm{C}$ não apresentaram brotação por seis meses. Entre os clones cultivados no outono, o maior período de dormência durante o armazenamento a $12^{\circ} \mathrm{C}$ foi observado no clone SMINIA793101-3, e a $25^{\circ} \mathrm{C}$ foi no clone Asterix. Em tubérculos produzidos na primavera, o maior período de dormência durante o armazenamento a $8^{\circ} \mathrm{C}$ foi observado nos clones SMINIA793101-3 e Missaukee, a $12^{\circ} \mathrm{C}$ foi no clone SMINIA793101-3, e a $25^{\circ} \mathrm{C}$ foi nos clones Asterix e Missaukee. Tubérculos produzidos na primavera continham maiores teores de massa seca e amido, maiores taxas respiratórias, e menores concentrações de açucares redutores e polifenóis totais. A única excessão foi o clone Missaukee que apresentou teores de matéria seca similares em ambas as épocas de cultivo. De modo geral, as temperaturas de armazenamento, $4^{\circ} \mathrm{C}$ e $8^{\circ} \mathrm{C}$, foram mais efetivas na redução da respiração e na prevenção da redução dos teores de matéria seca de tubérculos. Escurecimento de chip, concentração de açúcares redutores e polifenóis totais aumentaram durante o armazenamento dos tubérculos. Os maiores valores de escurecimento de chip, açúcares redutores e polifenóis totais foram obtidos com o armazenamento a $4^{\circ} \mathrm{C}$ e $8^{\circ} \mathrm{C}$. Os resultados sugerem que a melhor temperatura de armazenamento depende do genótipo, idade fisiológica do tubérculo, e condições de cultivo.

Palavras-chave: Solanum tuberosum, matéria seca, respiração, cor de chip, açucares redutores, polifenóis.

\section{(Recebido para publicação em 26 de abril de 2011; aceito em 14 de fevereiro de 2012) (Received on April 26, 2011; accepted on February 14, 2012)}

$\mathrm{P}$ rocessing quality of potato tubers is determined by high dry matter, and low reducing sugar and phenol contents (Kadam et al., 1991; Abong et al., 2009). High dry matter content increases chip yield, crispy-consistency, and reduces oil absorption during cooking (Pedreschi et al., 2005; Rommens et al.,
2010). Low reducing sugars and phenol contents are required to avoid dark color and bitter taste of processed products, which negatively affect consumer acceptance (Wiltshire \& Cobb, 1996; Wang-Pruski \& Nowak, 2004).

Dry matter of potato tubers and chip color are genetically controlled and influenced by environmental conditions during growing season and storage temperature (Kawchuk et al., 2008). Potato tubers grown in spring have higher dry matter content and shorter dormancy than tubers grown in autumn (De Freitas et al., 2006; Bisognin et al., 2008a). High storage temperatures 
hasten the reduction in sprout inhibitors and the increase in sprout promoters (Bhargava, 1997). Once sprouting is started, high rates of starch hydrolysis and reducing sugars accumulation are required to supply carbon and energy used for sprout growth and development, which negatively affect tuber processing quality by reducing dry matter and increasing dark color of potato chips (Wiltshire \& Cobb, 1996; Bisognin et al., 2008a). Storage temperatures lower than $6^{\circ} \mathrm{C}$ increase the activity of the enzymes that convert starch into fructose and glucose (Matsuura-Endo et al., 2004). Since the respiration rate and sprouting are inhibited by low temperatures, the consumption of reducing sugars is low and their content accumulates in the tubers, resulting in dark chip color (Coelho et al., 1999; Chapper et al., 2004; Knowles et al., 2009). In spite of apparent differences in storage behavior, the actual processes leading to reducing sugar accumulation are likely to be the same for different cultivars (Hertog et al., 1997).

In the southern region of Brazil, potato tubers can be cultivated in spring and autumn (Bisognin et al., 2008a). During spring growing season, the average environmental temperature, photoperiod, and irradiation increase from $15^{\circ} \mathrm{C}, 12 \mathrm{hs}$, and $4.11 \mathrm{MJm}^{2} /$ day to $22^{\circ} \mathrm{C}, 15 \mathrm{hs}$, and $24 \mathrm{MJm}^{2} /$ day, respectively (Bisognin et al., 2008b). During the autumn growing season, the average environmental temperature, photoperiod, and irradiation decrease from $28^{\circ} \mathrm{C}, 13 \mathrm{hs}$, and $19.9 \mathrm{MJm}^{2} /$ day to $12^{\circ} \mathrm{C}, 11 \mathrm{hs}$, and $4.63 \mathrm{MJm}^{2} /$ day, respectively (Bisognin et al., 2008 b). These opposite environmental conditions during spring and autumn growing seasons can potentially result in different processing quality of potato tubes during storage at different temperatures.

The objective of this work was to access the processing quality of potato clones Asterix, SMINIA793101-3, and Missaukee cultivated during spring and autumn growing seasons and stored at different temperatures.

\section{MATERIAL AND METHODS}

Tubers of the potato (Solanum tuberosum) clones Asterix, SMINIA793101-3, and Missaukee (Douches et al., 2010) were produced in the field in autumn (February to July) and spring (August to December) growing conditions of Julio de Castilhos (29\%13'37'S and $\left.53^{\circ} 40^{\prime} 54^{\prime \prime} \mathrm{W}\right)$, southern region of Brazil. Asterix and SMINIA793101-3 were chosen because of adaption to the environmental conditions, and Asterix is also widely cultivated in the southern region of Brazil. Missaukee was used as non-adapted clone that have high processing quality attributes (Douches et al., 2010). Seed production and crop management followed standard technical recommendations used in the region (Bisognin, 1996). After harvest, tubers were cured at $20^{\circ} \mathrm{C}$ and $85 \pm 5 \%$ relative humidity for 15 days. Tubers of each clone were then randomized and stored at $4,8,12$, and $25^{\circ} \mathrm{C}$ with $85 \pm 5 \%$ relative humidity. During storage, temperature and relative humidity were constantly monitored with an automated system (Fockink, Panambí, Brazil). The treatments were combinations among three clones $\mathrm{x}$ two growing seasons $\mathrm{x}$ four storage temperatures. The experiment followed a completely randomized design, with four replications per treatment and ten tubers per replication.

Number of days to reach one hundred percent sprouting was determined by counting the number of days that each replication required to reach one hundred percent sprouting (ten sprouted tubers). Dry matter, respiration rate, chip color, reducing sugars (glucose + fructose), total polyphenols, and starch content were analyzed at 0,90 , and 180 days of storage. The dry matter content was quantified in tubers dried in a forced air circulation oven at $60^{\circ} \mathrm{C}$, until constant weight. The respiration rate was calculated based upon the $\mathrm{CO}_{2}$ production of $500 \mathrm{~g}$ of potato samples sealed inside a $1 \mathrm{~L}$ container for about $5 \mathrm{~h}$. The $\mathrm{CO}_{2}$ concentration was determined by a $\mathrm{CO}_{2}$ analyzer (Agri-Datalog, Italy). Chip color was determined on ten potato slices $(2 \mathrm{~mm}$ thick) per replication. After being cut, potato slices were fried in hydrogenated vegetable oil at $185^{\circ} \mathrm{C}$ until ceasing oil bubbling. Chip color was then measured with a portable colorimeter (Minolta, CR310) through a CIE L*a*b* system, twice each replication. The values were expressed as $\mathrm{L}^{*}$, ranging from the black to white (higher values = lighter color). Reducing sugars were analyzed as described by Ross (1959). Briefly, $1 \mathrm{~g}$ of powdered dry tuber tissue was vortexed during $45 \mathrm{~s}$ with 5 $\mathrm{mL}$ of distilled water and centrifuged at $2000 \mathrm{x} \mathrm{g}$ for $10 \mathrm{~min}$. An aliquot of $2 \mathrm{~mL}$ of the supernatant was added to $0.5 \mathrm{~mL}$ of 2,4-dinitrophenol solution $(0.038 \mathrm{M})$. The samples were incubated at 65 to $70^{\circ} \mathrm{C}$ for $6 \mathrm{~min}$ and then cooled under running water. Reducing sugar concentrations were estimated at $600 \mathrm{~nm}$ spectrophotometrically. The total polyphenols concentration was determined using a $0.2 \mathrm{~mL}$ aliquot from the supernatant extracted for the reducing sugar quantification, which was added to $1 \mathrm{~mL}$ of Folin $(10 \%)$ with $0.8 \mathrm{~mL}$ of $\mathrm{Na}_{2} \mathrm{CO}_{3}(7.5 \%)$, according to Singleton \& Rossi (1965). For starch quantification, $250 \mathrm{mg}$ of powdered dry tuber samples were autoclaved for hydrolyzation in a solution of 10 $\mathrm{mL}$ of distilled water and $0.5 \mathrm{~mL}$ of concentrated $\mathrm{HCl}$ during $20 \mathrm{~min}$ at $120^{\circ} \mathrm{C}\left(1 \mathrm{kgf} / \mathrm{cm}^{2}\right)$. After cooling, the samples were then neutralized with $\mathrm{NaOH}(50 \%)$ to $\mathrm{pH}=7.0$. Then, $1 \mathrm{~mL}$ of the neutralized solution was added to $3 \mathrm{~mL}$ of distilled water and $0.5 \mathrm{~mL}$ of 2,4-dinitrophenol solution (0.038 M). After vortexing, starch concentrations were estimated based on the glucose concentration measured at $600 \mathrm{~nm}$ spectrophotometrically (Ross, 1959). Data were submitted to analysis of variance and treatment means compared by Tukey's test $(\mathrm{p}<0.05)$ or presented as mean \pm standard error.

\section{RESULTS AND DISCUSSION}

The individual and combined effects of clone, growing season, and storage temperature were statistically significant (p-value $<0.001$ ) for all parameters evaluated, with the exception of the clone versus storage temperature interaction for the variable total polyphenols (p-value $=0.354)$. Tubers stored at $25^{\circ} \mathrm{C}$ had about $40 \%$ decay and all tubers were senescent by 120 days of storage. 
Table 1. Tuber dry matter (\%), starch content (mg/g/dw), $\mathrm{CO}_{2}$ production $(\mathrm{mL} / \mathrm{kg} / \mathrm{h})$, chip color $(\mathrm{L})$, reducing sugars $(\mathrm{mg} / \mathrm{g} / \mathrm{dw})$, and total polyphenols $(\mathrm{mg} / \mathrm{g} / \mathrm{dw})$ of three potato clones produced in spring and autumn growing seasons and stored at four temperatures (4, $8,12,25^{\circ} \mathrm{C}$ ) for 180 days (massa seca de tubérculos $(\%)$, concentração de amido ( $\left.\mathrm{mg} / \mathrm{g} / \mathrm{ms}\right)$, produção de $\mathrm{CO}_{2}(\mathrm{~mL} / \mathrm{kg} / \mathrm{h})$, cor de chips $(\mathrm{L})$, açúcares redutores $(\mathrm{mg} / \mathrm{g} / \mathrm{ms})$ e polifenóis totais $(\mathrm{mg} / \mathrm{g} / \mathrm{ms})$ de trềs clones de batata produzidos na primavera e no outono e armazenados em quatro temperaturas $\left(4,8,12,25^{\circ} \mathrm{C}\right)$ por 180 dias). Santa Maria, UFSM, 2011.

\begin{tabular}{|c|c|c|c|c|c|c|}
\hline \multirow[t]{2}{*}{ Parameter } & \multicolumn{2}{|c|}{ Asterix } & \multicolumn{2}{|c|}{$\begin{array}{c}\text { SMI- } \\
\text { NIA793101-3 }\end{array}$} & \multicolumn{2}{|c|}{ Missaukee } \\
\hline & Spring & Autumn & Spring & Autumn & Spring & Autumn \\
\hline ry matter & $19.9 \mathrm{aA}^{\mathrm{a}, \mathrm{b}}$ & $15.6 \mathrm{cB}$ & $20.1 \mathrm{aA}$ & $17.7 \mathrm{bB}$ & $19.2 \mathrm{bA}$ & $19.1 \mathrm{aA}$ \\
\hline Starch & $500.0 \mathrm{bA}$ & $350.4 \mathrm{bB}$ & $526.9 \mathrm{aA}$ & $361.6 \mathrm{aB}$ & $429.3 \mathrm{cA}$ & $348.3 \mathrm{bB}$ \\
\hline $\mathrm{CO}_{2}$ production & $5.8 \mathrm{cA}$ & $3.4 \mathrm{bB}$ & $7.1 \mathrm{aA}$ & $3.6 \mathrm{abB}$ & $6.6 \mathrm{bA}$ & $3.9 \mathrm{aB}$ \\
\hline Chip color ${ }^{\mathrm{c}}$ & $49.5 \mathrm{bA}$ & $47.8 \mathrm{cB}$ & $49.0 \mathrm{bB}$ & $51.2 \mathrm{bA}$ & $52.8 \mathrm{aB}$ & $58.6 \mathrm{aA}$ \\
\hline Reducing sugars & $32.1 \mathrm{aB}$ & $71.1 \mathrm{aA}$ & $26.4 \mathrm{bB}$ & $36.1 \mathrm{bA}$ & $26.6 \mathrm{bB}$ & $28.3 \mathrm{bA}$ \\
\hline Total polyphenols & $1.9 \mathrm{aB}$ & $2.8 \mathrm{aA}$ & $1.7 \mathrm{bB}$ & $2.3 \mathrm{bA}$ & $1.6 \mathrm{bB}$ & $2.2 \mathrm{bA}$ \\
\hline \multicolumn{7}{|c|}{$\begin{array}{l}\text { a'Average values obtained from all storage temperatures and evaluation times during storage } \\
\text { (médias obtidas para todas as temperaturas de armazenamento e épocas de avaliação durante } \\
\text { o armazenamento); b Average values followed by the same letter, low case among clones } \\
\text { in each growing season and upper case between growing seasons, are not significantly } \\
\text { different ( }<<0.05 \text { ) according to Tukey's test (médias seguidas pela mesma letra, minúscula } \\
\text { entre clones em cada época de cultivo e maiúscula entre períodos de crescimento, não são } \\
\text { significativamente diferentes ( }<0,05 \text { ) segundo o teste de Tukey); "The "L" scale ranges from } \\
\text { black to white, higher values means lighter color (O "L" é uma escala que varia do preto ao } \\
\text { branco, valores mais altos significam uma cor mais clara). }\end{array}$} \\
\hline
\end{tabular}

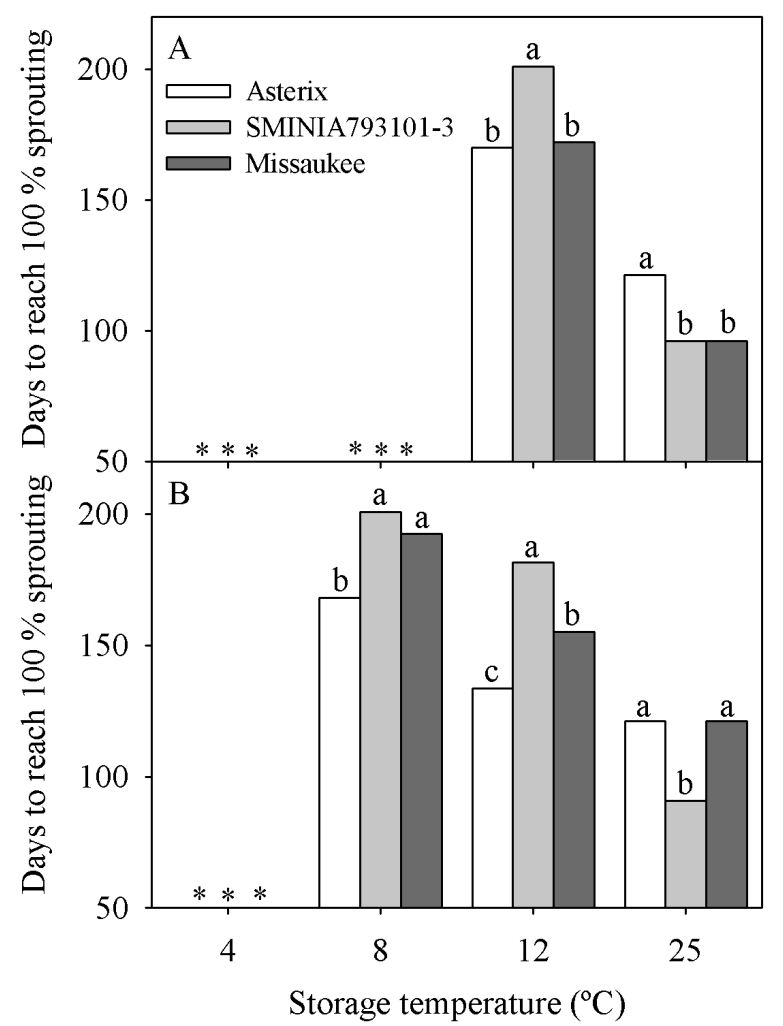

Figure 1. Number of days required for potato clones Asterix, SMINIA793101-3, and Missaukee to reach $100 \%$ sprouting at different storage temperatures. Clones grown in autumn (A), or spring (B). Bars followed by the same letter in each storage temperature do not differ by Tukey's test $(\mathrm{p}<0.05)$. No sprouted tubers $\left({ }^{*}\right)$ (número de dias necessários para os clones de batata Asterix, SMINIA793101-3 e Missaukee atingirem 100\% de brotação em diferentes temperaturas de armazenamento. Clones cultivados no outono (A), ou na primavera (B). Barras seguidas pela mesma letra em cada temperatura de armazenamento, não diferem pelo teste de Tukey $(\mathrm{p}<0,05)$. Tubérculos não brotados $(*))$. Santa Maria, UFSM, 2011.
Therefore, data from tubers stored at $25^{\circ} \mathrm{C}$ for 150 and 180 days were not considered in the analysis.

Tubers grown in spring had shorter dormancy than tubers grown in autumn when stored at 8 and $12^{\circ} \mathrm{C}$ (Figure 1). Tubers grown in spring and autumn and stored at $4^{\circ} \mathrm{C}$, as well as tubers grown in autumn and stored at $8^{\circ} \mathrm{C}$ had no sprouting after six months of storage. In both growing seasons, higher storage temperatures resulted in shorter tuber dormancy. Among clones grown in autumn, the longest dormancy period during storage at $12^{\circ} \mathrm{C}$ was observed in the clone SMINIA793101-3, and at $25^{\circ} \mathrm{C}$ was in Asterix. In potato tubers grown in spring, the longest dormancy period observed in storage at $8^{\circ} \mathrm{C}$ was in SMINIA793101-3 and Missaukee, at $12^{\circ} \mathrm{C}$ was in SMINIA793101-3, and at $25^{\circ} \mathrm{C}$ was in Asterix and Missaukee. These results are in agreement with previous studies showing that lower storage temperatures can extend dormancy, which is also determined by the growing conditions (Wiltshire \& Cobb, 1996; Bisognin et al., 2008a). In that case, determining the best storage temperature according to the growing season and processing time is important for extending tuber dormancy and obtaining the highest potato processing quality.

Asterix and SMINIA793101-3 tubers showed the highest dry matter content in spring and the lowest in autumn (Table 1). Missaukee had similar dry matter content in both growing seasons. All three potato clones grown in spring had higher starch content than potato clones growing in autumn (Table 1). SMINIA793101-3 showed higher starch content than the other clones in both growing seasons. These results could be explained by the fact that increasing photoperiod, temperature and irradiance with plant development during spring can enhance carbohydrate accumulation in the tubers (Bisognin et al., 2008b). The clone Missaukee showed similar dry matter content in both growing seasons, possibly due to a lack of adaptation to higher temperatures during tuber growth and maturation under spring conditions. Moreover, the concentration of starch 


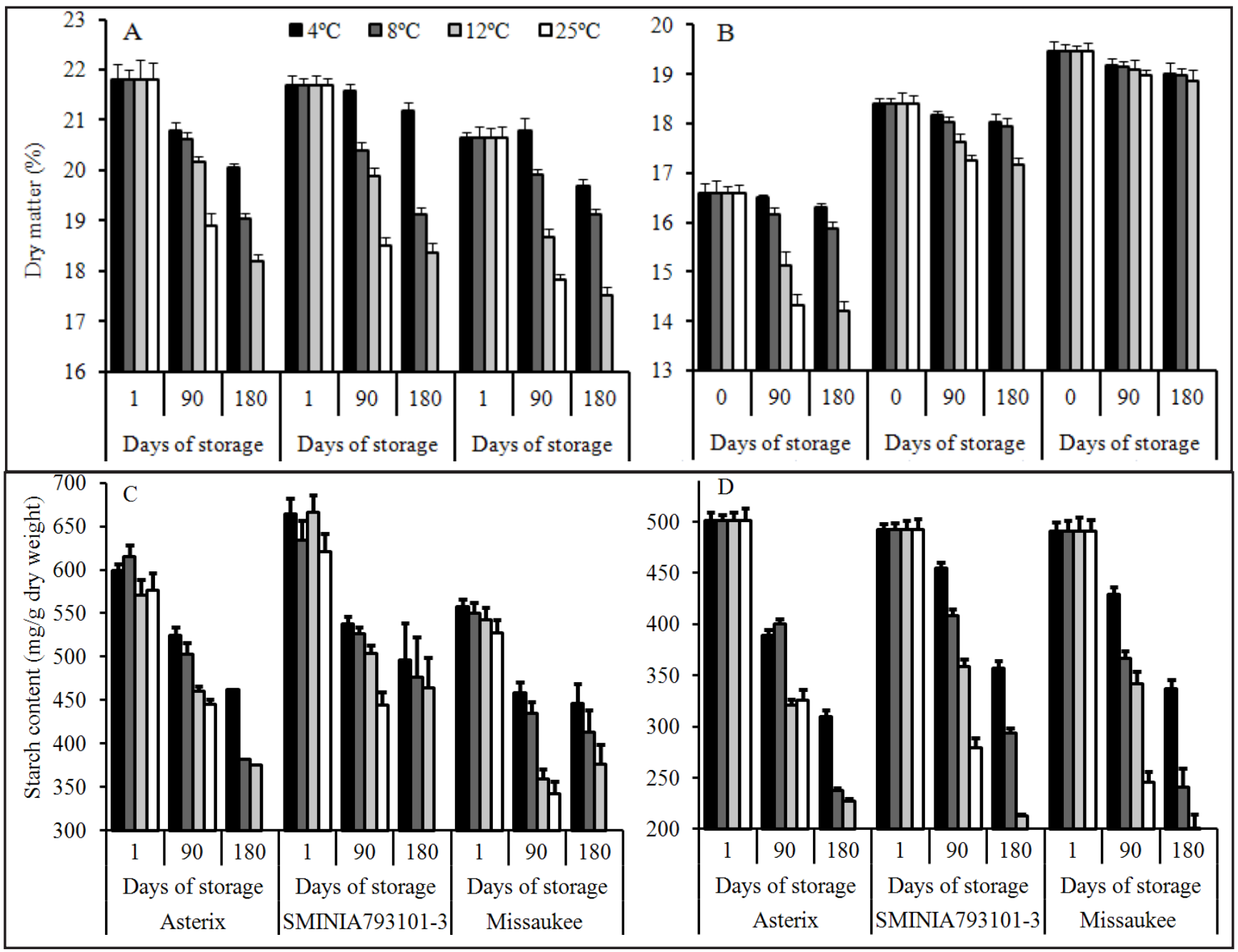

Figure 2. Dry matter (A and B) and starch content $(\mathrm{C}$ and $\mathrm{D})$ in tubers of three potato clones produced during spring $(\mathrm{A}$ and $\mathrm{C})$ and autumn (B and D) growing seasons and stored at four temperatures $\left(4,8,12,25^{\circ} \mathrm{C}\right)$ for 180 days. Bars indicate means \pm standard error. Potato tubers kept at $25^{\circ} \mathrm{C}$ were analyzed only until 90 days of storage [matéria seca (A e B) e concentração de amido (C e D) em tubérculos de três clones de batata produzidos durante a primavera $\left(\mathrm{A}\right.$ e C) e outono $(\mathrm{B}$ e $\mathrm{D})$ e armazenados em quatro temperaturas $\left(4,8,12,25^{\circ} \mathrm{C}\right)$ por 180 dias. As barras indicam a média \pm erro padrão. Os tubérculos de batata mantidos a $25^{\circ} \mathrm{C}$ foram analisados somente até os 90 dias de armazenamento]. Santa Maria, UFSM, 2011.

content observed in spring might not have been greatly affected the dry matter, since the tuber starch content of Missaukee was only $43 \%$ of the dry matter content. Therefore, similar values of dry matter content observed in the clone Missaukee in both growing seasons might be a result of the reduction in other dry matter components such as sugars, nitrogen compounds, lipids, organic acids, phenols, minerals, and non-starch polysaccharides (Kita, 2002). Considering that dry matter content is determined on tuber fresh weight (dry weight + water) basis, it is also possible that the similar dry matter content observed in the clone Missaukee in both growing seasons might be a result of different tuber water content between growing seasons.

The dry matter and starch contents decreased during storage for all potato clones produced in both growing seasons (Figure 2). Lower storage temperatures $\left(4\right.$ and $8^{\circ} \mathrm{C}$ ) tended to be more effective in maintaining dry matter and starch contents of the potato tubers than higher temperatures $\left(12^{\circ} \mathrm{C}\right.$ and $\left.25^{\circ} \mathrm{C}\right)$. It is known that higher temperatures increase metabolism, respiration and physiological aging of potato tubers, resulting in the observed earlier sprouting and higher carbohydrate consumption (Wiltshire \& Cobb, 1996). The direct relationship between dry matter and starch contents is expected, since starch usually represents most of the dry matter in potato tubers (Liu et al., 2003). In this work, the average starch content after 180 days of storage varied from $34.8 \%$ of the dry matter in the tubers of the clone Missaukee to $36.2 \%$ in the clone SMINIA793101-3 produced in autumn. However, when produced during the spring season they had starch average values of $42.9 \%$ and $52.7 \%$ of the dry matter, respectively. Previous works have shown that starch comprises 40 to $80 \%$ of the dry weight of tubers, depending on genetic and environmental factors (Kadam et al., 1991). All three clones produced in spring had shorter dormancy, which accelerated the reduction of tuber dry matter during 


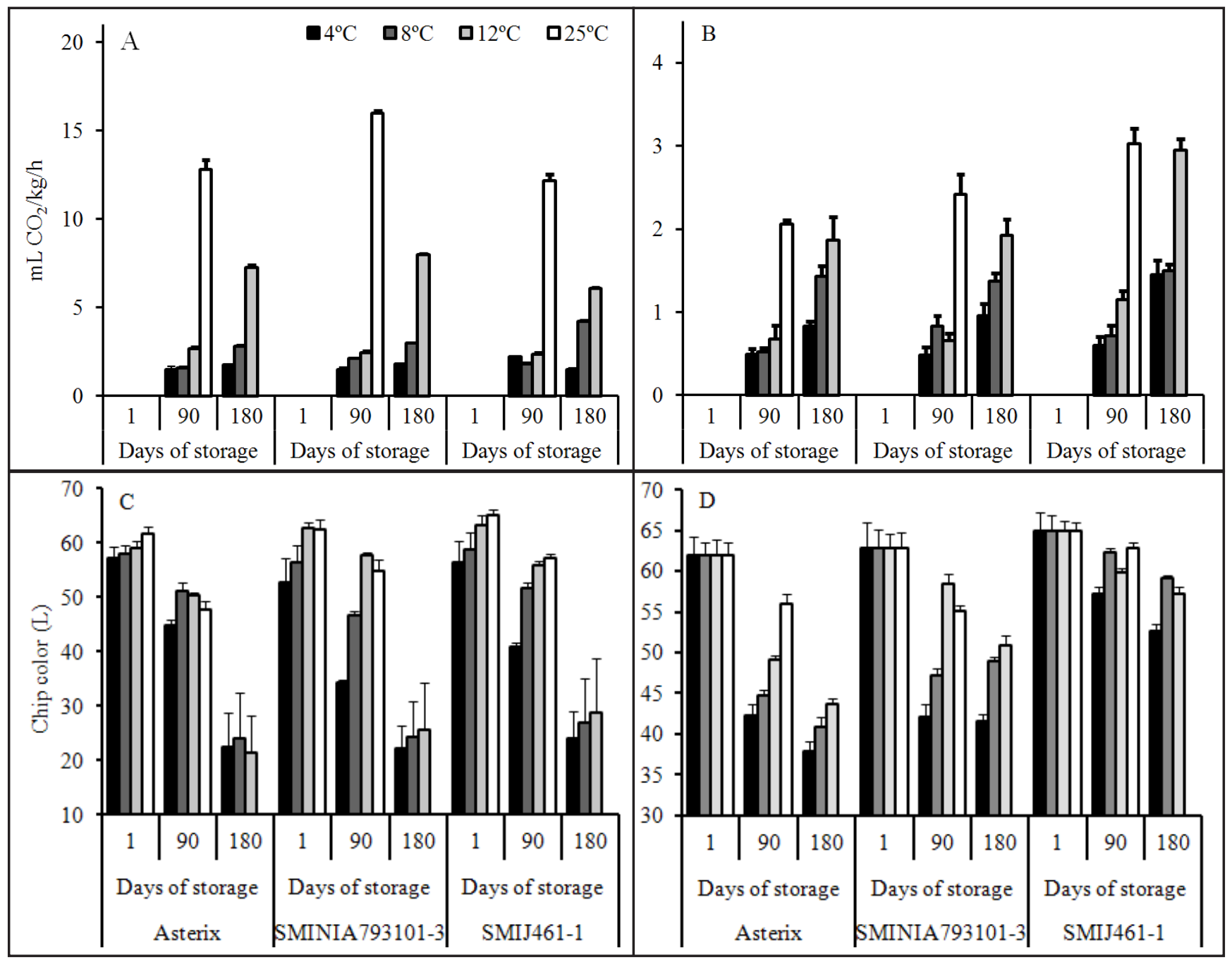

Figure 3. Respiration rate (A and B) and chip color (C and D) of tubers of three potato clones produced during spring (A and C) and autumn $(\mathrm{B}$ and $\mathrm{D})$ growing seasons and stored at four temperatures $\left(4,8,12,25^{\circ} \mathrm{C}\right)$ for 180 days. Bars indicate means \pm standard error. Potato tubers kept at $25^{\circ} \mathrm{C}$ were analyzed only until 90 days of storage. $\left(^{*}\right)<0.1 \mathrm{~mL} \mathrm{CO} / \mathrm{kg} / \mathrm{h}$ [taxa de respiração (A e B), cor de chips (C e D) de tubérculos de três clones de batata produzidos durante a primavera (A e C) e outono (B e D) e armazenados em quatro temperaturas $(4,8$, $12,25^{\circ} \mathrm{C}$ ) por 180 dias. As barras indicam a média \pm erro padrão. Os tubérculos de batata mantidos a $25^{\circ} \mathrm{C}$ foram analisados somente até os 90 dias de armazenamento. $(*)<0.1 \mathrm{~mL} \mathrm{CO} / \mathrm{kg} / \mathrm{h}]$. Santa Maria, UFSM, 2011.

storage at higher temperatures. When potato clones were produced in autumn, the dormancy period was longer, and the effect of increasing storage temperatures on dry matter consumption was lower. The clone Asterix showed similar trend in the reduction of dry matter content during storage in both growing seasons, which can be explained by the fact that different growing conditions had lower effect on Asterix tuber dormancy, compared to the other clones.

Tubers of all three clones grown in spring had higher respiration rates than tubers grown in autumn (Table 1 ). In both growing seasons, the lowest respiration rates were observed in
Asterix tubers. However, in autumn, the respiration rates were similar between Asterix and SMINIA793101-3 tubers. Lower storage temperatures of 4 and $8^{\circ} \mathrm{C}$ resulted in lower respiration rates in both growing seasons (Figures $3 \mathrm{~A}$ and $3 \mathrm{~B}$ ). Respiration rates increased markedly during storage of the tubers at $25^{\circ} \mathrm{C}$ (Figures $3 \mathrm{~A}$ and $3 \mathrm{~B}$ ). Tubers produced in spring had higher increase in respiration rates during storage in response to higher temperatures than tubers produced in autumn (Figures $3 \mathrm{~A}$ and $3 \mathrm{~B}$ ). These results may be explained by the fact that the faster physiological aging of the tubers produced during spring required higher metabolic activity for carbohydrate metabolism and energy production to support sprout growth (Wiltshire \& Cobb, 1996; Geigenberger $\&$ Fernie, 2007), which was accelerated by higher storage temperatures. It is well known that storage temperature is an important factor to minimize postharvest losses during storage of potato tubers. Respiration rates of potato tubers have been reported to have a minimum at about $4{ }^{\circ} \mathrm{C}$ and increase at higher temperatures (Wustman \& Struik, 2007). However, temperatures lower than $6^{\circ} \mathrm{C}$ may result in lower processing quality of potato tubers due to accumulation of reducing sugars (Coelho et al., 1999; Knowles et al., 


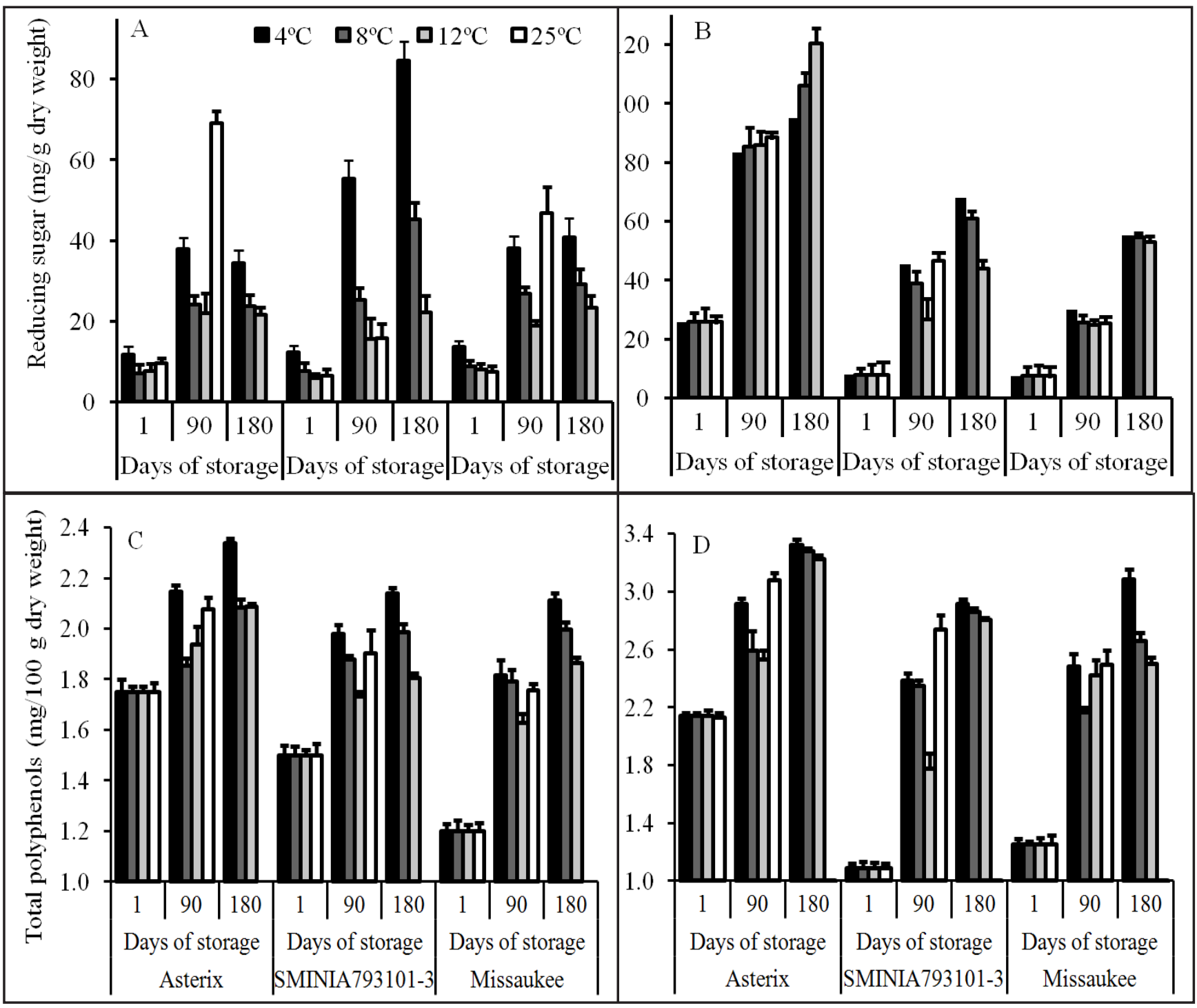

Figure 4. Reducing sugar (A and B) and total polyphenol (C and D) concentrations in tubers of three potato clones produced during spring $\left(\mathrm{A}\right.$ and $\mathrm{C}$ ) and autumn $(\mathrm{B}$ and $\mathrm{D})$ growing seasons and stored at four temperatures $\left(4,8,12,25^{\circ} \mathrm{C}\right)$ for 180 days. Bars indicate means \pm standard error. Potato tubers kept at $25^{\circ} \mathrm{C}$ were analyzed only until 90 days of storage [concentrações de açúcares redutores (A e B) e polifenóis totais (C e D) em tubérculos de três clones de batata produzidos durante a primavera (A e C) e outono (B e D) e armazenados em quatro temperaturas $\left(4,8,12,25^{\circ} \mathrm{C}\right)$ por 180 dias. As barras indicam a média \pm erro padrão. Os tubérculos de batata mantidos a $25^{\circ} \mathrm{C}$ foram analisados somente até os 90 dias de armazenamento]. Santa Maria, UFSM, 2011.

2009). In addition, different genotypes have different regulation of reducing sugar accumulation associated with tuber sprouting and senescence in response to high temperatures (Wiltshire \& Cobb, 1996). Therefore, to keep high processing quality of potato tubers during storage, it is necessary to find a suitable temperature that minimizes losses and reducing sugars accumulation.

All potato clones grown in spring had lower reducing sugars and polyphenol contents than potato clones grown in autumn (Table 1). The lightest chip color and the lowest reducing sugar content were observed in the clone Missaukee in both growing seasons (Table 1). Clones Missaukee and SMINIA793101-3 did not differ statistically in reducing sugar content in both growing seasons. Clones SMINIA793101-3 and Missaukee had lighter chip color when produced in autumn and Asterix showed lighter chip color when produced in spring (Table 1). Clones SMINIA793101-3 and Missaukee showed the lowest polyphenol content in both growing seasons. Chip color results from spring and autumn growing seasons showed that darkening was associated with higher reducing sugars content in the tubers, which is in agreement with previous studies (Rodriguez-Saona \& Wrolstad, 1997; De Freitas et al., 2006). Reducing sugars are substrates for the Maillard reaction, which produces pigments known as melanoidins with brown color and bitter taste (Wiltshire $\&$ Cobb, 1996). The darkest chip color obtained in Asterix tubers produced in autumn is possibly the result of 
a combination between the highest reducing sugars content and the lowest respiration rate observed in this clone. When Asterix was produced in spring, the tubers showed higher respiration rates, consuming more reducing sugars and resulting in a lighter chip color. Total polyphenol content in Asterix was also lower in tubers produced in spring, which probably enhanced the effect of low reducing sugars on lighter chip color. However, clones SMINIA793101-3 and Missaukee did not follow the same pattern of high reducing sugars and polyphenol content and darker chip color comparing potatoes produced in spring and autumn. The final chip color does not only depend upon the reducing sugars and polyphenol content, but also on the concentration of amino acids (lysine, glycine, glutamine and arginine), and protein in potato tubers (Saona \& Wrolstad, 1997), as well as the amount of acrylamide formation in fried chips (Pedreschi et al., 2005). In addition, previous studies presenting levels of reducing sugars similar to the ones observed in clones SMINIA793101-3 and Missaukee have shown that a high correlation between potato chip color and reducing sugar content can only be obtained if the concentration of sucrose is also considered (Shallenberger et al., 1959). Therefore, potato tubers of SMINIA793101-3 and Missaukee produced in spring possibly accumulated substances other than reducing sugars and polyphenols that contributed to the darkening of chip color. The involvement of these other substances in chip color development can also explain previous works showing different potato clones with different chip color and similar reducing sugar contents (Rodriguez-Saona \& Wrolstad, 1997; De Freitas et al., 2006).

Potato chip darkness increased during storage for all clones and the darkest values were obtained at $4{ }^{\circ} \mathrm{C}$ (Figures 3C and 3D). All three potato clones increased reducing sugar content during storage in both growing seasons (Figures 4A and 4B). In spring, higher reducing sugar content was observed in tubers stored at $4^{\circ} \mathrm{C}$, except for Asterix and Missaukee that also accumulated high reducing sugar content during storage at $25^{\circ} \mathrm{C}$ (Figure $4 \mathrm{~A}$ ). In autumn, the clone Missaukee had similar reducing sugar content in all storage temperatures (Figure 4B). At 180 days of storage, Asterix showed the highest reducing sugar accumulation at $12^{\circ} \mathrm{C}$ (Figure 4B). Tubers of SMINIA793101-3 produced in autumn accumulated higher reducing sugars during storage at $4^{\circ} \mathrm{C}$ and $25^{\circ} \mathrm{C}$ (Figure 4B). Storage temperatures lower than $6^{\circ} \mathrm{C}$ have been shown to decrease respiration rates, and increase the activity of enzymes responsible for the conversion of starch into reducing sugars in potato tuber, which results in high reducing sugar accumulation and dark color of potato chips (Coelho et al., 1999; Sowokinos, 2001; Chapper et al., 2004). However, the rate of starch depletion and soluble sugar accumulation depends upon storage temperature and cultivar, possibly owing to variation in enzyme activities (Kazami et al., 2000). This could explain the different clone responses to growing conditions and storage temperatures in relation to reducing sugar accumulation and chip color observed in our study. All three clones increased the reducing sugar content and the darkness of chip color during storage. This result is possibly the consequence of tuber aging process, in which amyloplast membranes increase permeability, resulting in higher starch degradation and reducing sugar accumulation (O’Donoghue et al., 1995).

Polyphenol content in potato tubers tented to increase during storage (Figures 4C and 4D). Tubers of all three clones produced during spring and stored at $4^{\circ} \mathrm{C}$ had the highest polyphenol content (Figure 4C). Asterix produced in autumn tended to accumulate higher polyphenols at low storage temperatures of 4 and $8^{\circ} \mathrm{C}$ (Figure 4D). Polyphenols are responsible for an enzymatic darkening, in which a ferrous-chlorogenic acid complex is formed during cooking and later oxidizes to a bluish-gray compound called ferri-dichlorogenic acid (WangPruski \& Nowak, 2004). In agreement with previous works, our results show that variations in polyphenol concentration in potato tubers are not only genetically controlled, but also influenced by environmental conditions (Percival \& Baird, 2000; Wang-Pruski \& Nowak, 2004).

The possibility to grow potato tubers in contrasting conditions of temperature, irradiance, and photoperiod in the southern region of Brazil was fundamental to exploit great differences in processing quality of potato clones growing in such conditions and stored at different temperatures. High processing quality of potato tubers is certainly not only determined by genetic makeup, but also by growing season conditions and proper storage temperatures. The clone Missaukee has the best processing quality with high and stable dry matter content and the lightest chip color in both seasons. Potato tubers produced in spring have higher dry matter and starch contents, but have shorter dormancy and store better for a shorter period of time, than potato tubers produced in autumn. Spring produced tubers requiring lower storage temperatures to extend the dormancy and maintain higher processing quality for a longer time than autumn produced tubers. Low storage temperature $\left(4^{\circ} \mathrm{C}\right)$ maintains low tuber respiration rates, which results in higher reducing sugar content and darker chip color. Higher storage temperature $\left(25^{\circ} \mathrm{C}\right)$ maintains lighter chip color, but enhances dry matter reduction in the tubers. The best storage temperature for processing potato tubers is in the range between 8 and $12^{\circ} \mathrm{C}$. To fine tune the best storage temperature, it is necessary to know tuber physiological age based upon cultivar and growing season conditions.

\section{ACKNOWLEDGEMENTS}

This work was financially supported by the National Council of Technological and Scientific Development (CNPq). We thank Dr. Adel Kader, professor at the University of California-Davis, who contributed with comments on an earlier version of this manuscript. We also thank all members of the Potato Breeding Program at the Federal University of Santa Maria for their collaborative efforts.

\section{REFERENCES}

ABONG GO; OKOTH MW; KARURI EG; 
KABIRA JN; MATHOOKO FM. 2009. Evaluation of selected Kenyan potato cultivars for processing into french fries. Journal of Animal and Plant Sciences 2: 141-147.

BHARGAVA R. 1997. Changes in abscisic and gibberellic acids contents during the release of potato seed dormancy. Biologia Plantarum 39: 41-45.

BISOGNIN DA. 1996. Technical recommendations for the cultivation of potato in Rio Grande do Sul and Santa Catarina. Santa Maria: UFSM's Press. $64 \mathrm{p}$.

BISOGNINDA;DEFREITASST;BRACKMANN A; ANDRIOLO JL; PEREIRA EIP; MULLER DR; BANDINELLI MG. 2008a. Physiological aging of potato tubers produced during fall and spring growing seasons and stored under different temperatures. Bragantia 67: 59-65.

BISOGNIN DA; MULLER DR; STRECK NA; ANDRIOLO JL; SAUSEN D. 2008 b. Development and yield of potato clones during spring and autumn. Pesquisa Agropecuaria Brasileira 43: 699-705.

CHAPPER M; BACARIN MA; PEREIRA AS LOPES NF. 2004. Amidolytic and acid soluble invertase activities in potato tubers stored under two temperature conditions. Ciencia e Agrotecnologia 22: 597-601.

COELHO AHR; VILELA ER; CHAGAS SJR. 1999. Frying quality of potato (Solanum tuberosum L.) as regards reducing sugar and starch levels during refrigerated and non refrigerated storage in modified atmosphere. Ciência e Agrotecnologia 23: 899-910.

DOUCHES DS; COOMBS J; FELCHER K; KIRK WW; LONG C; BIRD G. 2010. Missaukee: a round white potato variety combining chip-processing with resistance to late blight, verticillium wilt and golden cyst nematode. American Journal of Potato Research 87: 10-18.

DE FREITAS ST; BISOGNIN DA; GOMÉZACS; SAUTTER CK; COSTA LC; RAMPELOTTO MV. 2006. Processing quality of potato clones during spring and autumn grown conditions of Rio Grande do Sul. Ciência Rural 36: 80-85.

GEIGENBERGER P; FERNIE AR. 2007. Starch synthesis in the potato tuber. Iowa: Blackwell Publishing's Press. 270 p.

HERTOG MLATM; TIJSKENS LMM; HAK PS. 1997. The effects of temperature and senescence on the accumulation of reducing sugars during storage of potato (Solanum tuberosum L) tubers: A mathematical model. Postharvest Biology and Technology 10: 67-79.

KADAM SS; WANKIER BN, ADSULE NR. 1991. Potato production, processing and products. Boca Raton: CRC's Press. $35 \mathrm{p}$.

KAWCHUK LM; LYNCH DR; YADA RY; BIZIMUNGU B; LYNN J. 2008. Marker assisted selection of potato clones that process with light chip color. American Journal of Potato Research 85: 227-231.

KAZAMI D; TSUCHIYA T; KOBAYASHI Y; OGURA N. 2000. Effect of storage temperature on quality of potato tubers. Journal of the Japanese Society for Food Science 47: 851-856.

KITA A. 2002. The influence of potato chemical composition on crisp texture. Food Chemistry 76: 173-179.

KNOWLES NR; DRISKILL EPJ; KNOWLES LO. 2009. Sweetening responses of potato tubers of different maturity to conventional and non-conventional storage temperature regimes. Postharvest Biology and Technology 52: 49-61.

LIU Q; WEBER E; CURRIE V; YADA RY. 2003. Physicochemical properties of starch during potato growth. Carbohydrate Polymers 51: 213-221.

MATSUURA-ENDO C; KOBAYASHI A; NODA T; TAKIGAWA S; YAMAUCHI H; MORI M. 2004. Changes in sugar content and activity of vacuolar acid invertase during lowtemperature storage of potato tubers from six Japanese cultivars. Journal of Plant Research 117: 131-137.

PEDRESCHI F; MOYANO P; KAACK K; GRANBY K. 2005. Color changes and acrylamide formation in fried potato slices. Food Research International 38: 1-9.
O'DONOGHUE EP; YADA RY; MARANGONI AG. 1995. Low-Temperature Sweetening in Potato tubers - the Role of the Amyloplast Membrane. Journal Plant Physiology 145: 335-341.

PERCIVAL RG; BAIRD L. 2000. Influence of storage upon light-induced chorogenic acid accumulation in potato tubers (Solanum tuberosum L.). Journal of Agricultural and Food Chemistry 48: 2476-2482.

RODRIGUEZ-SAONA LE; WROLSTAD RE. 1997. Influence of potato composition on chip color quality. American Potato Journal 74: 87-106.

ROMMENS CM; SHAKYA R; HEAP M; FESSENDEN K. 2010. Tastier and healthier alternatives to French Fries. Journal of Food Science 75: 109-115.

ROSS AF. 1959. Dinitrophenol methods for reducing sugars. In: TALBURST WF; SMITH O (eds). Potato Processing: Connecticut. Avi Publishing Company. p. 467-470.

SHALLENBERGER RS; SMITH O; TREADWAY RH. 1959. Role of the sugars in the browning reaction in potato chips. Journal of Agricultural and Food Chemistry 7: 274-277.

SINGLETON VL; ROSSI JA. 1965. Colorimetric of total phenols with phosphoromolybdicphosphotugstic acid reagents. American Journal of Enology and Viticulture 20: 144158.

SOWOKINOS JR. 2001. Biochemical and molecular control of cold-induced sweetening in potatoes. American Journal of Potato Research 78: 221-236.

WANG-PRUSKI G; NOWAK J. 2004. Potato after-cooking darkening. American Journal of Potato Research 81: 7-16.

WILTSHIRE JJJ; COBB AH. 1996. A review of the physiology of potato tuber dormancy. Annals of Applied Biology 129: 553-569.

WUSTMAN R; STRUIK PC. 2007. The canon of potato science: Seed and ware potato storage. Potato Research 50: 351-355. 